While it is generally felt that the excessive excretion of porphobilinogen and $\delta$-aminolævulic acid in acute hepatic porphyria is due to over-production of these materials, the exact biochemical mechanism leading to such over-stimulation of the porphyrin pathway is still in doubt. Experiments designed to test the possibility of restricted conversion of glycine into serine were inconclusive. A hint as to the means by which $\delta$-aminolævulic acid production is normally regulated may be forthcoming from the experiments described by Shemin who showed, in one system studied, that $\delta$-aminolævulic acid is itself an inhibitor of the enzyme producing it. This points to the possibility of a negative feed-back control operating in the normal cell. The combination of administration of porphyrinogenic drugs with pantothenate deficiency promises to throw further light on the development of the nervous symptoms in acute porphyria. It has been generally assumed, since the self-experiment of Meyer-Betz, that photosensitization in the cutaneous porphyrias is actually caused by the porphyrins themselves. Direct evidence was lacking, however, until quantitative measurements were made by Magnus and collaborators on patients with the use of a powerful monochrometor. This technique and the results it afforded were described and exemplified by the case of a man with sun-burn type photosensitivity who, nevertheless, showed highest cutaneous sensitivity in the Soret band region of the spectrum. Further investigation showed that his red cells and freces did, in fact, contain abnormally large quantities of porphyrins.

The increase in urinary excretion of porphyrin which accompanies lead intoxication has aroused the interest of biochemists for many years, but is as yet little understood. New light may be thrown on this problem by the finding of Gajdos and his collaborators that lead ions interfere with the passage of iron through the membrane of the developing red cell, the stroma, under these conditions, retaining iron rather firmly.

The biochemical mechanism of incorporation of iron into protoporphyrin and the part played by 'bound' forms of these reactants, the biosynthesis of porphyrins by human leucocytes and the metabolism of hæmoglobin within the red cell were next considered. It would appear from the work of Schapira and his co-workers that the hæmoglobin molecule within the erythrocyte is not metabolically inert, but that progressive structural alterations occur with the course of time. The effects of radiation on the synthesis of hrmoglobin in the bone marrow, and the results of a great deal of work on the relation of porphyrin structure to $\mathrm{X}$-ray sensitivity, were also reported.

At the close of the meeting, Prof. C. Rimington endeavoured to lay before participants an appraisal of the most significant conclusions and to point to the fields from which the next major advances towards an understanding of normal and pathological porphyrin metabolism might be expected to come. He took the opportunity of thanking the organizers and the two bodies sponsoring the colloquium for their excellent work on behalf of porphyrin biochemistry and for their generous hospitality. This meeting will be long remembered with gratitude and pleasure by those who were gathered together in the stimulat. ing atmosphere of Saclay.

\section{Rimington}

\title{
CONSERVATION OF BRITISH NATIONAL PARKS
}

\begin{abstract}
T its recent eleventh annual report the National 1 Parks Commission referred briefly to the question of afforestation in the National Parks, especially on Dartmoor and Exmoor, and also to its disappointment at the delay in amending the Act, particularly with regard to financial resources. Both these aspects have since been the subject of short adjournment debates in the House of Commons. In the first of these, on March 29, Mr. E. du Cann raised the question of afforestation, particularly in the Dartmoor and Exmoor National Parks. While supporting the voluntary agreement recently reached between the Timber Growers" Organization, the Country Landowners' Association, the Forestry Commission and the National Parks Commission regarding afforesta. tion in the National Parks, Mr. du Cann questioned whether a voluntary agreement would be sufficiently effective, as it did not include all those concerned with afforestation in such areas.
\end{abstract}

In his reply, the Parliamentary Secretary to the Ministry of Housing and Local Government, Sir Keith Joseph, agreed that it was important to give the new scheme a fair trial. He thought that there was no reason to fear that landowners in the areas concerned, who were not members of the Association, would not, as individuals, comply with such agresments and, in reply to a specific question about trees on High House Moor, Dartmoor, said that discussions were still proceeding between the proposed developers and the authorities. On this specific issue it should be noted that considerable uneasiness still exists that the National Parks Commission will not be supported. The parties to the agreement were not despondent as to the prospects that the agreement would succeed, and Sir Keith Joseph appeared to have substantial grounds for his confidence that the spirit of co-operation already demonstrated by the production of this voluntary agreement, and the way it had been received and implemented indiceted that, with common sense, it should be possible to reconcile the claims of forestry and the National Parks and the rights of landowners.

Nevertheless, Sir Keith recognized that failure of the scheme would create a new situation and this would have to be faced. Meanwhile, he said, the Minister wished to give the scheme a fair trial and he made it clear that he also wished that all concerned, whether members of the particular organiza. tions or not, should participate in this voluntary consultation at all times. The Minister and the National Parks Commission would keep progress under careful review.

On the wider issue raised in the debate on March 30 , progress also may be regarded as largely a matter of co-operation and common sense, but on the part of the Government common sense implies providing the financial means to the end enacted. The root of the difficulties encountered in the development of 
the National Parks lies in the failure of the Government to provide, under the National Parks and Access to the Countryside Act of 1947, the finance required to make the provisions of the Act effective. Under that Act the responsibility for the National Parks was placed within the planning system set up by the Town and Country Planning Act of 1947 instead of the national system envisaged by the Hobhouse Committee. The counties provide two-thirds of the Committee members and almost all the funds, although some of these counties are among the poorest in the country.

Nevertheless, the system has worked surprisingly well, though it is obviously unfair to expect local authorities to take a national point of view, and invariably set the national interest before local interests, particularly at heavy cost to the ratepayers who elect them. The advantages of close association with local interests are such, however, that in view of this experience, it seems highly probable that, given quite moderate Government support, sufficient, for example, to ensure the provision of adequate planning staff and a reasonable contribution to the capital costs of positive projects of development, the existing system could well be continued with success. Much could be done if the National Parks Commission had an annual sum of even as little as $£ 100,000$, in place of the present $£ 20,000$ (with some $£ 5,000$ in Exchequer grants to the National Parks), which it could use at its discretion, either in helping the weaker authorities to strengthen their planning staffs, or in assisting projects which, at present, the park planning authorities hesitate to undertake because of their fear to place excessive burdens on local ratepayers for the benefit of outsiders.

Such a system admittedly is pragmatic rather than the ideal national system, in which national purposes and projects are financed directly from national funds, as Mr. F. H. Hayman advocated on March 30. Admittedly, the development and preservation of the National Parks is often too dependent on the finance committee of the county councils concerned, as $\mathrm{Mr}$. Hayman pointed out ; but to transfer the whole cost of the National Parks to national funds is not the only way of overcoming the difficulty, and if such a transfer lost local interest in, and support for, the National Parks the price might well lead to local misunderstanding and opposition. Mr. Hayman did not, however, appear to advocate quite such a drastic step though he made it clear enough that local resources and prejudices should not determine the objectives and purposes of a national undertaking.

In replying on this debate, Sir Keith Joseph asked for specific examples of projects which were now being frustrated by lack of funds, but claimed that direct Parliamentary grant, and not discretionary payment, was the appropriate way to finance public schemes. $\mathrm{He}$ confirmed that the Minister would look at all proposals made to him for amending the Act and said that he was at present seeking more information from the National Parks and the National Parks Commission to assist in this review. Sir Keith was emphatic that there was much more which could be done by the individual Park Committees which would receive Exchequer aid up to 75 per cent, but he thought the time might well have come to extend the legislative framework in some ways. Nevertheless, he did not think that finance was the only answer. Vigilance, effective administration and an imaginative approach must also play an important part, and probably the main value of both debates lies in the extent to which they demonstrate the need for public co-operation and understanding, and for such unceasing vigilance if the purposes of other Parks or Nature Reserves are to be served.

The whole subject was further discussed in the House of Lords on April 19 on a motion of Lord Silkin, who again stressed the importance of adequate financial provision. Lord Feversham also pointed out that existing provisions were completely in. adequate, either to prevent or to control fires on heaths and moors, and Lord Dalton, who agreed as to the need for adequate financial provision, also pressed the claims of the long-distance footpaths. Lord Chorley specifically suggested that the National Parks Commission should have an annual sum of $£ 150,000$ at its disposition, and like most other speakers was critical both of the Electricity Authorities and of afforestation, though tribute was freely paid to the sympathetic attitude of the Forestry Commission and its present chairman. Earl Jellicoe, who replied on the debate for the Government, added little to what had been said in the Commons by Sir Keith Joseph, but referred particularly to Lord Feversham's suggestion of a direct Treasury grant to the National Parks Commission.

\section{THE RESEARCH COUNCIL OF ALBERTA}

$\mathrm{T}$ HE forty-first annual report of the Research Council of Alberta covers the year 1960*, and includes a list of publications for 1956-60, and lists of members of Advisory and Technical Advisory Committees and of the staff of the Research Council. The Petroleum Division of the Fuels Branch has largely completed its work on the movement of oil in the presence of water in a pipe-line, and studies on capsule pipe-line transportation indicate that the presence of capsules in a flowing stream does not significantly alter pressure gradients, nor does the moving core appreciably distort the flow in the annulus. The capsule velocity appears to depend directly on capsule

* Research Council of Alberta. Forty-first Annual Report, 1960 Pp. $\mathbf{*}+55$. (Report No. 80.) (Edmonton: Anuarch Council of Pp. v+55. length and inversely on capsule diameter. The Division has also completed the first major phase in developing a generalized mechanism for the control of composition and accumulation of crude oils and natural gases in sedimentary basins, and the light paraffinic oils, which are usually found in positions corresponding to the areas of maximum depth of sedimentary basins, appear to owe their paraffinic constitution to the extensive action of oxidation and microbiological attack, both of which tend to destroy the less-resistant components of the developing crude oil. With the Coal Division the Petroleum Division is studying the transport of mixtures of pulverized coal and oil, while the Coal Division has also studied the combustion of pulverized fuel, the crystal structure 